ECPS Leader Profile Series

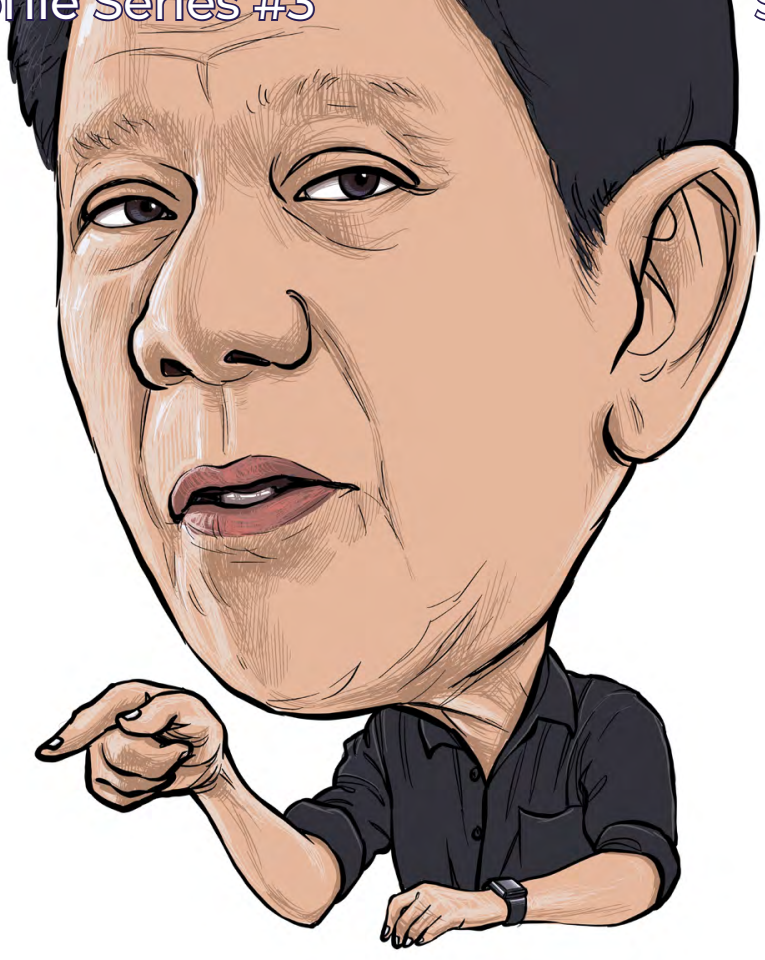

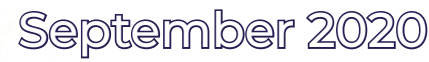

AUTHOR: Bulent Kenes

\title{
Rodrigo Roa Duterte: A Jingoist, Misogynist, Penal Populist
}

\section{ECPS}




\section{Rodrigo Roa Duterte: A Jingoist, Misogynist, Penal Populist}

BY BULENT KENES

\section{ABSTRACT}

Around the world, populists are associated with economically irresponsible and unsustainable policies. In Duterte's case, the action-oriented dimension is demonstrated through his tough rhetoric and policies against criminal and anti-social activity, particularly the use of illegal drugs. This is described as the new penal populism.

BULENT KENES is an academic and a journalist who has over 25 years of professional experience. He has managed multiple publications, both in Turkish and English.

ECPS Leader Profile Series offer analyses of political leaders and prominent public figures with populist tendencies. Unless otherwise indicated, the views expressed by the author are only attributable him and not to any institution with which they are associated.

The profile available for free downloading from the ECPS website (www. populismstudies.org)

(c)ECPS 2021 


\section{Table of contents}

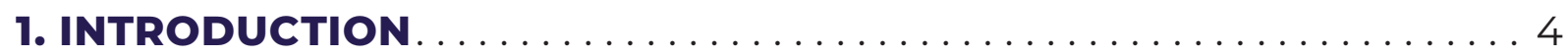

2. A POPULIST PUBLIC AND DUTERTE'S PRESIDENCY $\ldots \ldots \ldots \ldots$. . .

3. PENAL POPULISM AND DUTERTE'S “WAR ON DRUGS" .........12

4. DUTERTISMO: DEMISE OF DEMOCRACY .................. 16

5. DUTERTE MAKES NEW FRIENDS FROM OLD ENEMIES OR VICE

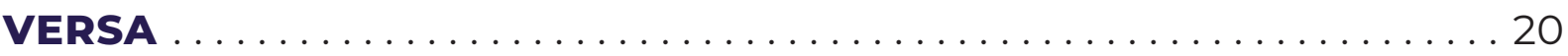

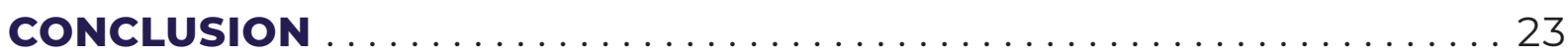

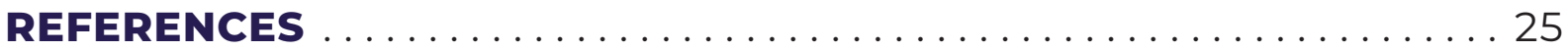




\section{INTRODUCTION}

On May 9, 2016, Filipinos voted to elect their 16th president. Among the candidates, Rodrigo Roa Duterte was the last one to join the campaign; and yet, he won despite a controversial reputation established during his long political career as a mayor of Davao City. During the campaign, Duterte promised to establish a similar regime to the one he established in Davao City - a regime that would restore "law and order" across the Philippines. He truthfully admitted that he was not going to be gentle with "criminality in general and drug lords in particular" and that his presidency might turn violent. Nevertheless, this crude rhetoric didn't stop the people from giving Duterte their votes (Panarina, 2017). Immediately after his inauguration, public trust in him skyrocketed to 91 percent. His success lies in his ability to connect to the masses, a trick he learned during his school years (The Famous People, 2020).

Rodrigo Duterte was born on March 28, 1945, in Maasin, Philippines. His father, Vicente G. Duterte, was a lawyer; later, he became the acting mayor of Danao and, following that, the provincial governor of the Davao province. Rodrigo's mother, Soledad Roa, was a teacher and a civic leader. Rodrigo was the second of five children. He started his education in Maasin, but within one year, the family moved to Davao City, where Rodrigo was admitted to Santa Ana Elementary School. His high school education was not smooth. After being expelled from two schools for unruly behavior, he was finally admitted to the High School Department of the then Holy Cross College in Digos, where he ultimately completed his schooling.

As governor of Davao, Duterte's father was often absent. His mother was a stern disciplinarian who forced him to attend strict Catholic schools where he was allegedly molested by an American priest. To escape the strictures of life at home and at school, he often ran with his father's police bodyguards, who introduced him to guns, booze, and life on the street (Vatikiotis 2018). He enjoyed hanging around with them and became street-smart, picking up their vocabulary and mannerisms. Although it caused immense trouble during his school days, the experience later helped him to connect with the masses (The Famous People, 2020).

Speaking of his high-school years, Duterte admitted that he shot one of his classmates. As The Enquirer explains, the student bullied Duterte (Fe, 2016) and got shot for it (although he luckily lived). It is worth mentioning other examples of Duterte's violent behavior, such as his statements on personally killing three criminals as mayor of Davao. He said: "I killed about three of them... I don't know how many bullets from my gun went inside their bodies. It happened and I cannot lie about it." He also added: "In Davao, I used to do it [kill] personally. Just to show to the guys [police] that if I can do it why can't you" (BBC News, 2016).

In 1988, Duterte was elected mayor of sprawling Davao City on the island of Mindanao. During the following decade, he was twice reelected. Due to term-limit restrictions, he did

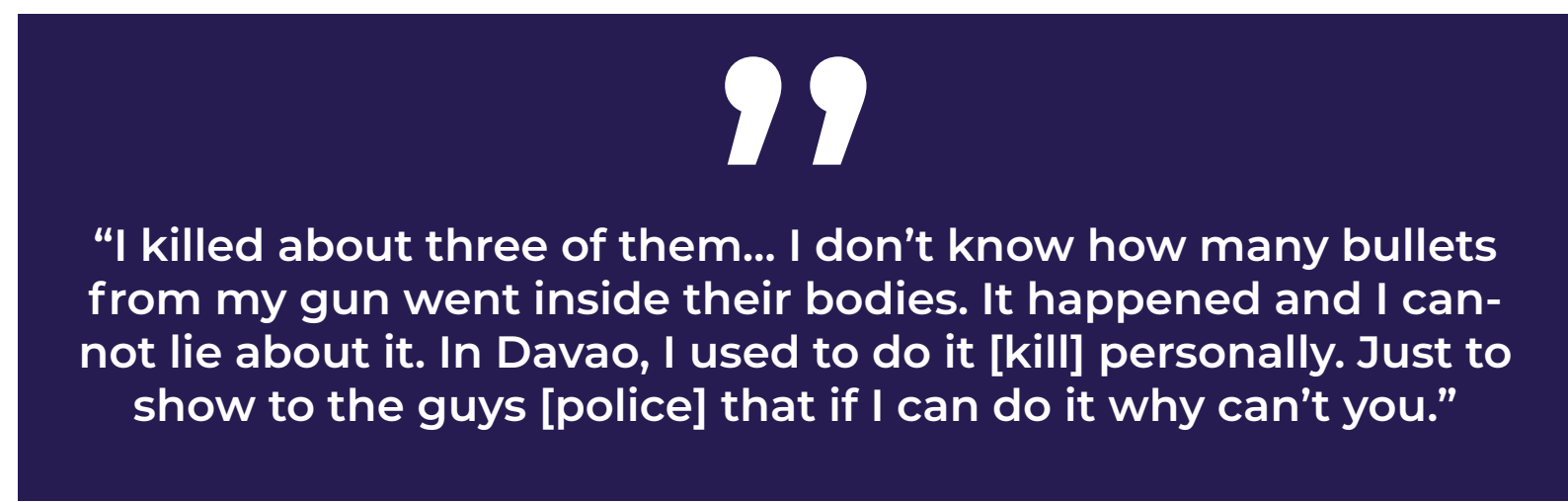


not run for mayor again in 1998 but successfully sought a seat in the Philippines House of Representatives, representing Davao. Upon the completion of that term in 2001, he returned to Davao City and was once more elected mayor. The restrictions were imposed again in 2010; he occupied the position of vice-mayor while his daughter Sara served as mayor. In 2013, Duterte returned to the mayor's office, this time alongside his son Paolo ("Pulong") (Panarina, 2017).

In Davao in the mid-1980s, communist rebels fought against the military and police-backed vigilantes in a gruesome dirty war. Violence killed people almost daily. Duterte was known as a tough city official in touch with both vigilantes and communists for political ends. As mayor, he was widely praised for cleaning up the city by using death squads and extrajudicial executions (Guthrie, 2018). He legitimized the activities of the Davao Death Squad (DDS), which many human rights organizations believe led to the deaths of 1020-1040 civilians from 1998 to 2005 (Quimpo 2017, p. 157). The DDS was composed of ex-army officers, police officers, and rehabilitated criminals who took justice into their own hands by killing suspected drug users, dealers, and petty criminals. DDS members were given "shoot-to-kill" orders for those resisting arrest (Tusalem, 2019).

During his more than two decades as Davao mayor, Duterte managed to transform the city into one of the safest areas in Southeast Asia. His radical crime-fighting tactics earned him the nicknames "the Punisher" and "Duterte Harry" (in reference to the film character Dirty Harry). Rather than denying extrajudicial killings in Davao City, he embraced them. The death squads that carried out the killings operated with impunity and Duterte openly praised both their methods and their apparent results. In this way, he cultivated the image of a coarse, pistol-toting vigilante, which he would utilize during the presidential campaign in 2016 (Ray, 2020).

In 2016, the socio-political conditions in the Philippines were ripe for any populist candidate like Duterte to be elected. The life of a common Filipino has been complicated by inadequate infrastructure, ineffectual government, old-hat political leaders, and governments dominated by a few affluent families. All of these factors helped Duterte to win the hearts of the people despite not being a complete outsider in Filipino politics. His family originally came from Cebu, where they were also involved in politics (Kundu, 2016). Duterte's "One Voice, One Nation" slogan referred to his background as a Manila outsider. In the classic mode of the "anti-politician politician," he sought to distance himself from the discredited politics of the capital city (McCargo, 2016). Duterte's success in restoring peace and order in Davao City led to his immense popularity among Filipinos who exhausted with an elitist political system blighted by corruption, bureaucratic inefficiency, and political instability (Curato 2017c).

Duterte's reputation grew as he took his political reputation to the national stage and found a country receptive to the message he would deliver via social media and elsewhere: drugs are a scourge, and he would use any means necessary to end the problem (Guthrie, 2018). While Duterte's responses to questions about vigilante connections were ambiguous and contradictory, he clearly relished his reputation as a ruthless anti-crime candidate. But while Duterte talked equally tough on corruption, he soon became embroiled in controver-

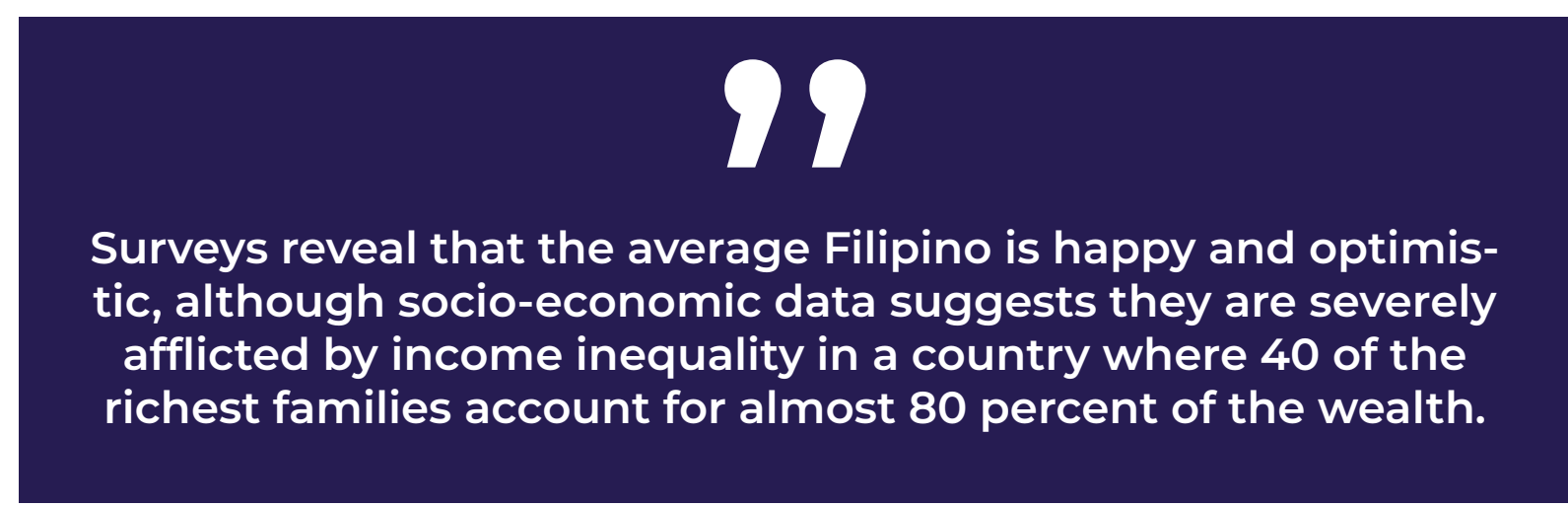


sy over his own bank accounts (Santos, 2016).

The Philippines, a country of more than 106 million people, is an odd basket of contrasts. The faster the country grew, the more obvious its poverty became. The rich got richer, the corrupt escaped jail, crime rates soared, and Manila's creaky infrastructure groaned under the weight of its populace. Measures of inequality in the Philippines soar above its regional neighbors, with a Gini coefficient of more than 44 and poverty rates above 20 percent; the murder rate, at close to 9 percent, is the highest in Southeast Asia (Vatikiotis, 2018). Despite these stats, surveys reveal that the average Filipino is happy and optimistic, although socio-economic data suggests they are severely afflicted by income inequality in a country where 40 of the richest families account for almost 80 percent of the wealth. Starved of opportunities at home, almost 12 percent of the population live or work overseas. And yet Philippine society is deeply nationalistic and given to fits of jingoism. In this context, Duterte's appeal becomes more understandable (Vatikiotis 2018).

Electoral polling data from the 2016 election suggest that even as he won votes across socio-economic classes, Duterte's strongest base of support comprised younger, wealthier, and more educated sections of the population (Ramos, 2020). This appears to be borne out by polls conducted a month before the elections, on the basis of which Teehankee and Thompson (2016a) opine that "the Duterte phenomenon is not a revolt of the poor. It is middle-class driven. It is angry protest most acute among the modestly successful, including call-center workers, Uber drivers, and overseas Filipino workers." Similarly, Coronel (2019) notes that among Duterte's most "hardcore supporters" are the "new middle classes," comprising Filipino nannies, nurses, seamen, and construction workers working overseas and the digital underclass working in the booming call centers in Manila and other cities. They constitute a section of the population for whom the global division of labor has provided pathways out of poverty but not necessarily into affluence and security. It is not difficult to see how Duterte's electoral pitch to deal with issues of criminality and the country's crumbling urban infrastructure would resonate with them (Ramos, 2020).

At the core of Duterte's public image were two closely interwoven themes: authenticity and masculinity. His authenticity was a challenge to the high-class backgrounds of both incumbent Benigno Aquino III and Aquino's anointed candidate, Mar Roxas (Kundu, 2016). Duterte delighted in code-switching between Tagalog and English; the Philippine Daily Inquirer dubbed him the "trash-talking mayor" for his constant swearing in both languages. Duterte did not hesitate to curse anyone and everyone - even Pope Francis, whom he called a "son of a whore." He flaunted his crudity as a marker of his maleness, boasting of his womanizing (Ranada, 2015), claiming that he wished he had raped an Australian missionary (ABC News, 2016); after the election, he catcalled a female reporter at a press conference (Youtube, 2016).

Duterte's open disdain for women, crude jokes, and foul language only seemed to burnish his allure (Guthrie, 2018). Much of that vulgarity is misogynistic and homophobic, and John Andrew G. Evangelista explores the contradiction of how a country with some of Asia's highest ratings for gender equality could produce a president prone to rape jokes and unwanted kisses. "Duterte did not make politics sexist," Evangelista explains. "It was already sexist to begin with,"(Capozzola, 2018).

In a forum where he first indicated his interest to run for president, Duterte said, "If only to save this Republic, I can run for President." He warned the audience of an "imminent disaster" if illegal drugs, criminality, and stalled peace talks are not resolved. For Duterte, the nation is on the brink "of being fractured," and it takes a leader who can say, "if you don't follow the law, you're fucked with me." Duterte's framing of fighting illegal drugs as a major election issue gained traction, evidenced by a poll where low pay and illegal drugs became some of the top issues concerning voters (Pulse Asia, 2016). This is a change from the usual issues that survey respondents identify outside the electoral season, where jobs, poverty, and inflation are among the top concerns; illegal drugs are rarely part of this list (Curato, 2017a). 
After some internal disputes within the party, Åkesson was proposed by the nomination committee to be the new SD leader in 2005. At the party congress on May 7, 2005, Åkesson won a vote over former party leader Mikael Jansson (Widfeldt, 2015). Since 2005, Åkesson has remained party leader. In the 2006 election, the SD significantly increased its support in the municipality of Sölvesborg, more than doubling their seats in the municipal council and winning almost ten percent of the votes. As party leader Åkesson participated in a number of debates and hearings on both television and radio (jimmieåkesson.se).

On October 19, 2009, Aftonbladet published a debate article by Åkesson that was critical of Islam. The article argued that various phenomena associated with Islam were the "greatest foreign threat to Sweden since World War II." The article highlighted Muslims as Sweden's biggest foreign threat (Åkesson, 2009). It received massive attention and reaction. Åkesson met Business Minister and Deputy Prime Minister Maud Olofsson in a live debate on SVT (Stensson, 2009). The Center for Racism applied to the Swedish Attorney General (Justitiekanslern - JK) about the article potentially inciting violence against various ethnic groups (Aftonbladet, 2009). JK did not, however, consider that the article's content constituted incitement against an ethnic group and decided not to initiate an investigation about it (Justitiekanslern, 2009).Despite reactions from political and intellectual circles, an opinion poll conducted by United Minds Opinion Institute and Synovate in October 2009 found that the debate had increased support for the SD (Brors, 2009). In February 2010, the DSM magazine released a survey showing that according to 150 leading Swedish writers, debate editors, chroniclers, and social debaters, Åkesson was Sweden's 9th most crucial opinion leader (Brors, 2010).

In the 2010 general election, the SD passed the 4 percent national election threshold for the first time and entered the Riksdag with 5.70 percent of all votes, gaining 20 seats (Nyberg, 2010). Åkesson was elected together with 19 of his fellow party members. In 2013, Åkesson published his autobiography Satis Polito (Åkesson, 2013). Fokus magazine ranked Åkesson as Sweden's 5th most powerful person of the year (Fokus, 2013).

In September 2014, Sveriges Radio's (SR) Ekot reported that Åkesson spent about 500,000 Swedish kron $(\$ 70,000)$ on online betting in 2014 alone. The sum is more than a politician could earn in a year after tax (The Local, 2014). The revelation caused an uproar, both among people who view Åkesson as unreliable and those who opposed SR's decision to publish the information. Åkesson called SR's actions an attempt at "character assassination" (Eriksson \& Olsson, 2014). Following the 2014 election, Åkesson announced he would be on sick leave due to burnout, during which Mattias Karlsson became temporary party leader (Holender et al, 2014). In early 2015, Åkesson was named as Sweden's most important opinion leader of 2014 by DSM; the authors of the piece claimed that he had changed the political landscape (DSM, 2015) of the county. In an interview with Fredrik Skavlan on March 23, 2015, Åkesson announced his gradual return to Swedish politics (Lisinski, 2015). 


\section{7}

Duterte often used shock tactics in his rhetoric. The phrase "I killed ... / I will kill you" was featured in two of his discourses. He used machismo as an overarching amplifier that allowed him to appeal to his supporters. This amplification strengthened his support and contributed to the masculine image he had built.

In Duterte's case, his use of gutter language lends credibility to the urgency of saving the republic. By rendering the visceral rejection of the status quo visible, he gives voice to the peoples' frustration. His main campaign message was the suppression of criminality and drugs within three to six months. He offered no clear economic platform, except for a vague proposal of a shift to the federal system. His currency is his promise of certainty, anchored on the rhetoric of violence and machismo (Curato, 2017a). During his election campaign, Duterte's main slogan was "Change is Coming," but this was no Obama-like evocation of the audacity of hope. The word "change" was invariably paired on Duterte posters with a clenched fist, more resembling a threat than a promise. Other slogans included the rousing "Go, Go!", the idealistic "One Voice, One Nation," and the more ambiguous Tagalog "Tapang at Malasakit (courage and devotion)." All were accompanied by the ubiquitous fist (McCargo, 2016).

Duterte often used shock tactics in his rhetoric. The phrase "I killed ... / I will kill you" was featured in two of his discourses. He used machismo as an overarching amplifier that allowed him to appeal to his supporters. This amplification strengthened his support and contributed to the masculine image he had built. Machismo is designed deliberately to amplify existing support from audience members (Ismail et al., 2018). Most controversially, he has made no bones about using extrajudicial violence to eliminate crime. During the campaign, Duterte warned that he would be killing people once he got elected: "When I become president, I'll order the police and the military to find [criminals and drug pushers] and kill them." Duterte declared in the final weeks of his campaign: "The funeral parlors will be packed ... I will supply the dead bodies." (Vatikiotis, 2018).

Wielding raw charisma, coarse language, and an unapologetic indifference to the norms of public behavior, Duterte's no-nonsense political style represented a fresh take on traditional electoral campaigns in the Philippines, in a way that spoke to people's sensibilities (Fink-Hafner, 2016; Taggart, 2004; Teehankee \& Thompson, 2016b). His tough talk sparked the hearts of voters fed up with the incumbent administration's inability to live up to its narrative of good governance (Holmes, 2016). Anchored on national frustration and anger (Teehankee, 2016), Duterte's campaign speeches generated captivat- 
ing stories of discontent and outrage over an inefficient and corrupt government.

Duterte invoked a crisis narrative of widespread criminality and illegal drug use, which generated illegal profits for the entrenched elite. Throughout his campaign, he cited a figure of anywhere from 3 to 4 million drug users in the country to justify his anti-drug campaign, although the Dangerous Drugs Board of the Philippines pegged the number at around 1.8 million (Gavilan, 2016). Through iron-fisted leadership, Duterte vowed to eliminate the drug problem in 3 to 6 months, even at the expense of human lives (David, 2016).

\section{7}

Populism may not be new to the Philippines, but Duterte's style is a departure. While Joseph Estrada and Jejomar Binay were often compared to Thailand's Thaksin Shinawatra, whose anti-elite rhetoric and pro-poor programs were tainted by scandals and corruption, Duterte's brand of populism is often compared to that of Donald Trump. 


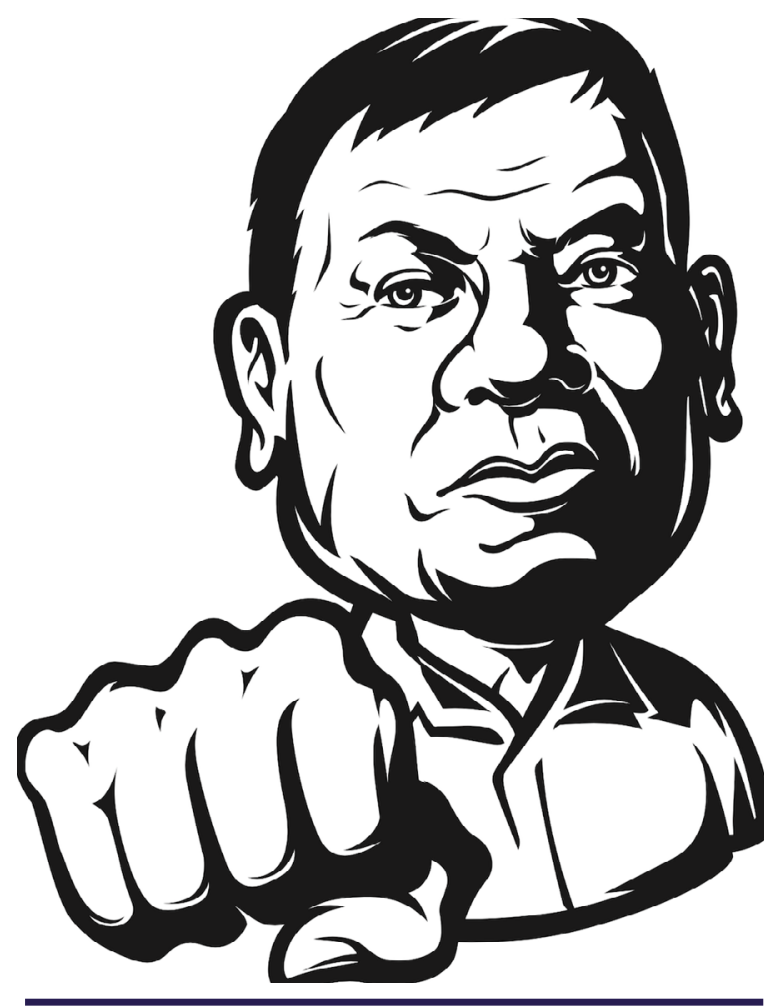

\section{A Populist Public and Duterte's Presidency}

On May 9, 2016, nearly 80 percent of eligible voters turned out for the election, and Duterte captured nearly as many votes (39 percent, or 16 million votes) as his two closest competitors combined (Ray, 2020). His "change" and "courage" image was that of a fearless pugilist, single-handedly taking on the forces of darkness.

This narrative drew on the Davao mayor's reported links to vigilante groups credited with killing dozens or even hundreds of drug-dealers (Whaley, 2016).Duterte's promise of a country free from drugs and criminality resonated with the public's concern for peace and order. Election exit polls showed that 57 percent of voters who voted for Duterte did so on the basis of his drug-war platform (Mangahas, 2016).

There are various ways to account for Duterte's rise to power. His brand of populism is one of the most compelling approaches to making sense of his electoral victory. Duterte was chosen as the people's champion against an oppressive and corrupt political establishment (Abts \& Rummens, 2007; Moffitt \& Tormey, 2014). This is consistent with previous literature on populism, which documents how populist leaders construct society as separated between "the pure people" and "the corrupt elite" (Mudde, 2010). Populism may not be new to the Philippines, but Duterte's style is a departure. While Joseph Estrada and Jejomar Binay were often compared to Thailand's Thaksin Shinawatra, whose anti-elite rhetoric and pro-poor programs were tainted by scandals and corruption, Duterte's brand of populism is often compared to that of Donald Trump (Curato, 2017a). Duterte's "anti-elitist" stance appears to be directed only at those sections of the elite outside his own governing coalition (Ramos, 2020).

Many firsts characterized the 2016 Philippine elections. It saw the electoral victory of Duterte, the first Filipino local politician to directly leapfrog to the presidency (Heydarian, 2018). Duterte's election also reflected an emerging trend of rising populism around the world (Arguelles, 2017; Curato, 2017a). This international surge of populism has not only resulted in populist leaders but also what Curato (2017c) calls, the "populist publics." According to Curato, the scandalous statements and incessant improprieties that have defined populists have also characterized their respective populist publics. "Populism is about populist publics as much as it is about populist leaders," she wrote. Thus, at a gathering of supporters in Manila, Duterte's "public" brought placards that read, "Those who will not vote for Duterte will get killed!" (Clement, 2016).

This perceived fanatical character of many populist supporters earned them pejorative labels. Rivals of Duterte have labeled his supporters as "Dutertards," a contraction of "Duterte" and "retard." This wave of ridicule and mockery was not only limited to populist critics. Even in academic literature, it is common for populist supporters to be represented in negative terms (Arguelles, 2019). Yet it's important to remember that Duterte won a majority of his support from the upper and middle classes (Holmes, 2016; Teehankee \& Thompson, 2016a).

In the past decades, the Philippines has witnessed an electoral cycle vacillating between "reformism" and "populism," 
with both sides having sometimes won the support of poor voters, who are admittedly more populist (Thompson, 2010). The populist Filipinos offer their support to Duterte in exchange for changes in how they are represented in public, how politics is conducted, and how the government is managed (Arguelles, 2019). As an example, many residents of Kalayaan, which is one of the many poor villages in the country targeted by Duterte's brutal operations against drug operations, still continue to support him in the face of the extrajudicial killings (Arguelles, 2018).

For the populist public, a vote for Duterte is a vote to make their everyday misery visible (Christie, 2009). Despite widespread international and domestic criticisms of his drug war policy, the populist public sees it as a recognition of their hidden suffering (Curato, 2018). Support for Duterte also reflects the populist publics' demand to bring authenticity to Philippine politics. In the eyes of the populist public, Duterte possesses both transparency and consistency. By being authentic, Duterte is seen to be more trustworthy, predictable, and relatable - characteristics that allowed a politician like him to easily get the political support of the populist public (Arguelles, 2019).

By being open about his personal failings and moral weaknesses, Duterte is seen by his supporters as ordinary. The populist public considers him to be more predictable and accessible, as they understand the state of mind of an "ordinary" person. As Schaffer (2007) noted in his study of slum communities, they gravitated to politicians who may be corrupt but can accord them respect and dignity. Hypocrisy repulsed the populist public on two counts: one, they despised that politicians considered themselves to be morally better individuals than ordinary people; and two, they were offended that these politicians would think they, the public, could be easily fooled (Arguelles, 2019).

The populist publics also voted for Duterte to overcome perceived bureaucratic inertia. For his supporters, Duterte is seen as a representation of a persistent political will. To these voters, the persistence of political will is demonstrated when politicians are determined to overcome all impediments, including legal challenges, just to be able to do pursue their desired course of action. These voters demand that politicians refrain from using the complexity of the bureaucracy as an excuse. In Duterte's case, his unresponsiveness to the criticisms of his controversial drug war policy is seen as proof of this. Duterte's supporters interpreted his disregard for due process and the rule of law not only as persistence and determination to fulfill his campaign promises but also as a form of solidarity with them in resisting the faceless but powerful bureaucratic rules (Arguelles, 2019).

Around the world, populists are associated with economically irresponsible and unsustainable policies that bureaucrats tend to reject (Rodrik, 2018), including unconditional cash transfers, free social services, and huge infrastructure projects. (Pasuk \& Baker, 2008). In Duterte's case, the action-oriented dimension is demonstrated through his tough rhetoric and policies against the criminal and anti-social activity, particularly the use of illegal drugs. This is described as the new penal populism (Curato, 2017c; McCoy, 2017b; Pepinsky, 2017): Duterte's supporters are drawn to his war-on-drugs policy on the premise that the existing legal system and institutions are used by the illegal drug industry to their advantage. For Duterte and the populist publics, if the order is to be restored in the country, what is needed is a strong and decisive leadership instead of strengthening the rule of law (Arguelles, 2016). 


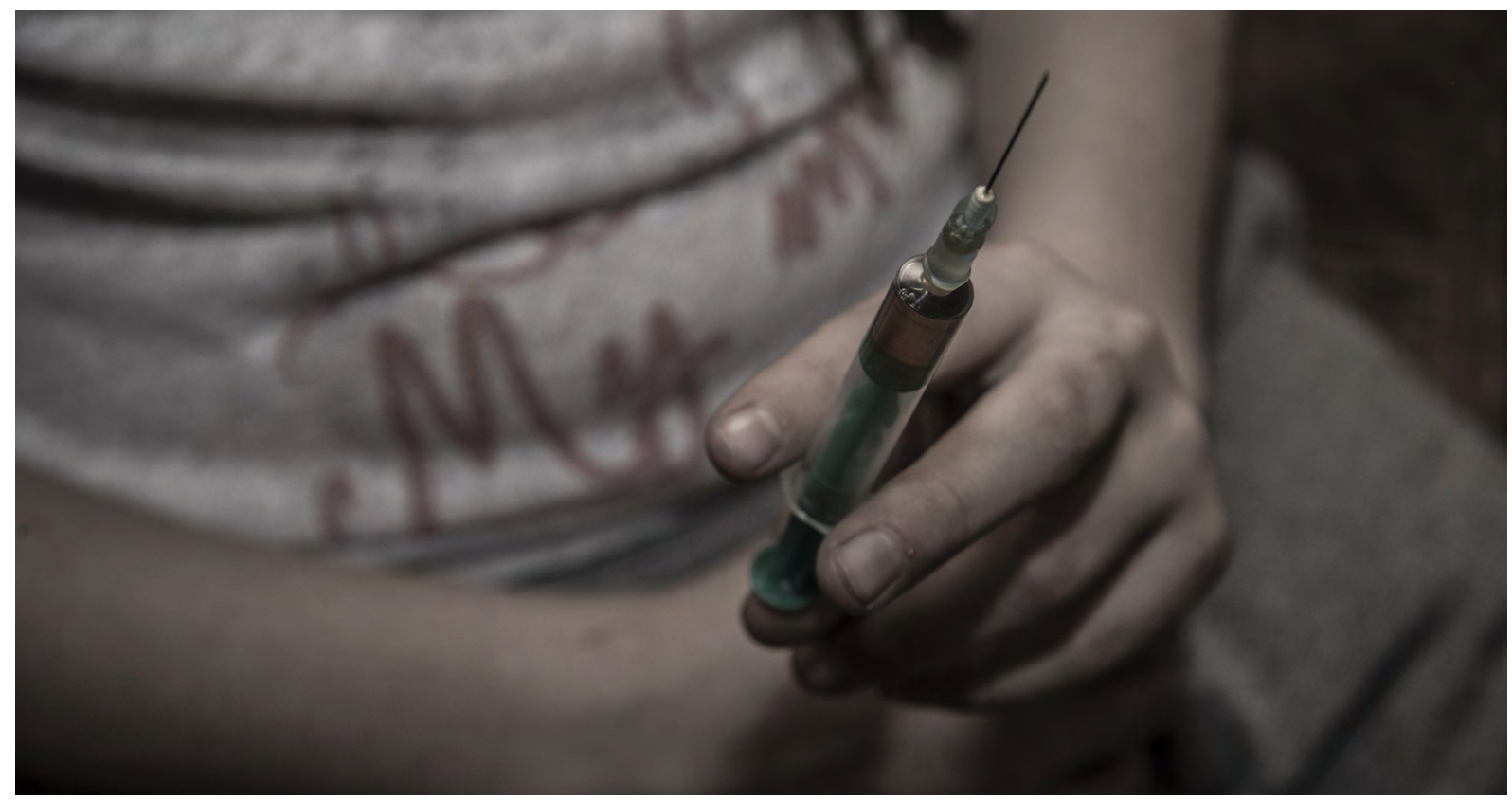

\section{Penal Populism and} Duterte's "War on

\section{Drugs"}

Duterte justified his "war on drugs" by exaggerating the security threats imposed by the illegal drug trade and, in turn, used this war as an instrument to incorporate the national police into his power base (Quimpo, 2017). This also resonates with the rhetoric of a strand of the new right and populist leaders with whom Duterte currently shares the world stage. This strand of populism has been described as "penal" or "punitive" (Curato, 2016). It involves the political practice of courting votes by preying on citizens' anxieties about security and safety, through the promotion of punitive short-term solutions to address criminality, often at the expense of respecting human rights (Ramos, 2020).

The ideology of penal populism has a positive relationship, on the provincial-level, with extra-judicial killings. For example, it has been found that extra-judicial killings are more likely to occur in provinces where Duterte's vote-share in 2016 was highest and in provinces that he regularly visited and where he gave speeches justifying his war on drugs. These findings comport with theories relating to how chief executives of representative democracies may increasingly rely on vertical accountability from citizens to extract continued political legitimacy given that horizontal checks on their power remain weak and ineffective. The results also imply that penal populism is an ideology that is used not only as a campaign tactic or strategy to win elections but as a program of government (Tusalem, 2019). Duterte also increased visits to certain

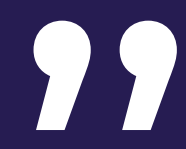

Because of his systematic attacks on human rights, Duterte was called as "fascist original". Of course, Duterte doesn't seem to care - he likened himself to Adolf Hitler and said that he would "be happy" to exterminate three million methamphetamine users and sellers in the country. He said, "If Germany had Hitler, the Philippines would have [points to himself]". 
provinces to promote and sell his anti-drug crusade through landmark fiery speeches, which are often laden with profanities and appear to be popular with the masses (Lamchek, 2017). This is clearly a tactic used by presidents in delegative democracies as a way to connect with the public to guarantee continued support (Tusalem, 2019).

By definition, penal populism is a virulent type of populism where leaders run on a platform of law and order in an effort to exploit fear and anxiety from their citizens. It is also an ideology that portrays how a country's political and economic instability can be traced to failures in the justice system and where policies and legislation are perceived by citizens as favoring criminals and neglecting the plight and concerns of law-abiding citizens and victims of heinous crimes (Curato,2017b; Kenny, 2018). This is also corroborated by Kenny's $(2017,2018)$ analysis of Philippine politics. Such support for a pernicious form of populism is not directly related to a declining economy; rather, support for "law-and-order" political leaders is driven by stoking generalized fear in the population because of the lack of institutionalized parties that are programmatic (Tusalem, 2019).

As a matter of fact, citizens in more developed provinces are more likely to endorse and support Duterte's penal populism. Such strong support for penal populism in affluent provinces and in provinces where Duterte won by large margins may also embolden police authorities to carry out the will of the majority. Conversely, poorer provinces, where narrower income inequalities exist, are less likely to prioritize crime victimization and crime insecurity in electoral campaigns, as their votes are based on addressing immediate, pressing concerns like poverty, hunger, and employment(Tusalem, 2019). Penal populism resonates with a public whose experience of justice is mostly of its elusiveness. Around 80 percent of drug cases in the country end up being dismissed, and it may take a decade to achieve a conviction. The demand for immediate action plays on the temptations of swift justice (Arguelles, 2019).

However, penal populism comes with a cost: because of his systematic attacks on human rights, Duterte was called as "fascist original" (Bello, 2017). Of course, Duterte doesn't seem to care - he likened himself to Adolf Hitler and said that he would "be happy" to exterminate three million methamphetamine users and sellers in the country. On September 30, 2016, he said, "If Germany had Hitler, the Philippines would have [points to himself]" (Lema \& Mogato, 2016). Committing mass violence with impunity and with public adulation, Duterte is the most dangerous president in the post-dictatorship Philippines. In fact, Simangan (2018) argues that his war on drugs is a "textbook case for what the processes of genocide look like."

Within days of his landslide victory, Duterte vowed to reintroduce the death penalty - abolished in the Philippines in 2006- in concert with his promise to "fatten all the fish" in Manila Bay with the bodies of criminals. In a televised address in June, he endorsed vigilantism by members of the public, stating that he would personally reward anyone who shot and killed a drug dealer. On June 30, 2016, Duterte was inaugurated as president of the Philippines (Ray, 2020). In his inaugural address, he read a short and powerful speech free from expletives. He assured the public that he knows the limits of presidential power and vowed to adhere to due process and the rule of law. However, hours after his inauguration, Duterte started cracking jokes about the profitability of funeral parlors under his administration (Curato, 2017a).

At the turnover ceremonies of the Philippine National Police and Armed Forces of the Philippines, he once again resorted to off-the-cuff speeches. "There is time to rest and to die," he said, pertaining to drug lords. And, in perhaps one of the most controversial moves of his first month in office, he publicly named top police generals, judges, and politicians who were part of the illegal drug trade (Curato, 2017a). His drug war soon led the National Police (PNP) to carry out extrajudicial killings of presumed drug dealers (Timberman, 2019). When the police become the sole executor in the war on drugs, it makes obeying other rules even more difficult. In the 2016-2018 period, Duterte fired more than 400 police offi- 
cers who were proven to have violated various regulations. Duterte eventually even offered to take over the leadership of the PNP himself (Aminuddin, 2020). Duterte openly followed a policy of reestablishing "law and order" by using authoritarian and militaristic methods. These have been heavily criticized by Western democratic societies but have rapidly earned him the "trust" of ordinary people (Panarina, 2017).

The violence precipitated by the war on drugs, the use of murder as a tool of public policy, and the open disregard for law and the courts is nothing new in the Philippines. Presidents, warlords, politicians, and various kinds of insurgents have been murdering with impunity in the country for generations. Duterte just took things a step farther, turning the use of death directed against the underclass into a political selling point. Duterte learned the tactic when he cut his political teeth as a prosecuting attorney in Davao City at the end of the dictatorial Ferdinand Marcos era. Marcos also used wars against drugs to justify violence, albeit on a more modest scale than Duterte (Guthrie, 2018).

Duterte's disregard for human rights has been the most worrisome aspect of his administration. "Human rights cannot be used as a shield or an excuse to destroy the nation," he declared in his first State of the Nation Address, a direct retort to his critics including human rights advocates, academics, and the Roman Catholic Church. One month after Duterte took office, there had been over 900 drug-related killings, 700 anti-illegal drug operations, 700 arrests, and hundreds of thousands of voluntary surrenders all over the country, further crowding jail cells already serving over five times their maximum capacity (Curato, 2017a).

In his first six months in office, more than 6,000 people were killed in Duterte's "war on drugs," many by vigilante groups; a fraction of those deaths occurred during police operations. Metro Manila's funeral parlors were strained beyond capacity, and hundreds of unidentified or unclaimed bodies were interred in mass burials. Human rights organizations and Roman Catholic officials spoke out against the bloodshed, but Duterte responded by accusing the church of cor- ruption and the sexual abuse of children (Ray, 2020). Duterte's "war" can be seen as his key instrument for delivering on his electoral campaign promise. He treats the purported "drug menace" as an issue of criminal justice, rather than as a public health concern (Tomacruz, 2018). These extra-judicial killings of suspected drug pushers and addicts by the police and vigilante groups deprive the victims of the recourse to due process (Ramos, 2020).

The death toll has continued to rise. In two years, police shot and killed around 4,800 people (Guthrie, 2018), although human rights activists suspect the body count could be as high as 12,000-15,000. According to the Brookings Institute and Human Rights Watch, the figure is between 9,000 and 12,000; the political opposition in the Philippines has the number at 20,000 (Tusalem, 2019); and the head of the Philippines Commission on Human Rights has said the death toll from the policy may be as high as 27,000 . Duterte has reveled in the bloodletting, barely bothering to deny his role in mass death (Guthrie, 2018). Most of the victims are denizens of urban slums and disproportionately poor; the drug war has rightly been described by international organizations as a "de facto program of social cleansing" and a "war on the poor" (Hadro, 2017).

Most victims come from poor socio-economic backgrounds. More specifically, many are unemployed or did not complete their primary or secondary education (Tusalem, 2019). The victims - often young male breadwinners from poor families -are dismissed as "collateral damage" of a war meant to keep the streets safe (Curato, 2019). Photojournalists have documented almost nightly killings in slums: people found slumped in pools of blood. A few of the killings have been caught on CCTV cameras.

Beyond the grisly spectacle of bloodied bodies, are grieving wives and orphaned children. Nearly 800,000 supposed drug users have surrendered to authorities and volunteered for rehabilitation. Unfortunately, there isn't the infrastructure to cope with this volume of treatment. Meanwhile, a 2017 survey revealed that eight out of ten Filipinos fear that they 
may become victims of the war on drugs yet, a similar number nonetheless support the campaign (Vatikiotis, 2018).

This fear is not baseless. The crackdown on drugs has resulted in the deaths of elected city officials and even Catholic priests. Duterte has shown no remorse. Yet, confoundingly, he remains popular. He may have silenced his critics using extra-judicial means, sacking the Supreme Court chief justice in the process, but he continues to deliver on key parts of his promise to address chronic problems. While Duterte draws most of his attention because of the war on drugs and his foul-mouthed disregard for women and religion, as a populist leader, he is moderately successful (Vatikiotis, 2018). In June 2019, a survey showed the public's satisfaction with the war on drugs at 82 percent (Reuters, 2019). The popularity parallels that of pro-poor social programs, infrastructure development, and military pay raises. Duterte's populist policies continue to earn major support from the low and middle classes and the urban poor (Aminuddin, 2020).

The pace of these gross human rights violations has alarmed scholars with concerns that the country is moving toward a situation where creeping authoritarianism is making a comeback, thus eroding the democratic gains the country has achieved since 1986 with the overthrow of the Marcos dictatorship (Curato 2017c). What also confounds scholars is that this act of state repression has been endorsed and supported by citizens. National surveys conducted by Pulse Asia in September 2017 suggest that 88 percent of Filipinos support the Oplan-Tokhang movement (as Duterte's "war on drugs" is known) and 86 percent believe that the campaign is orderly and does not violate the due process rights of Filipinos(Tusalem, 2019).

In July 2017, the Tom Lantos Human Rights Commission, a bi-partisan formation in the United States House of Representatives, conducted a public hearing on the human rights consequences of the war on drugs in the Philippines (Tom Lantos Human Rights Commission, 2017). In February 2018, the International Criminal Court (ICC) opened a preliminary investi- gation into the more than 12,000 deaths that had occurred during Duterte's "war." The following month, Duterte responded by announcing his intention to withdraw the Philippines from the ICC (Ray, 2020). Lashing out at the ICC investigation, Duterte said during a speech on Sept. 27, 2018, "What is my sin? Did I steal even one peso? Did I prosecute somebody who I ordered jailed? My sin is extrajudicial killings" (Guthrie, 2018). The Philippines' withdrawal from the ICC became official in March 2019 (Ray, 2020).

In June 2019, international human rights experts from the United Nations issued a statement calling on the UN Human Rights Council to investigate the human rights situation in the Philippines, in the face of the "staggering number of unlawful killings and official attacks on people and institutions who defend human rights" (Cumming-Bruce, 2019). International and domestic human rights organizations have continued to remain sharply critical of Duterte, but he has dismissed them, going so far as to instruct police to shoot activists if they are "obstructing justice" (Ray, 2020).

In October 2018, Rappler - an online news organization which published investigative pieces that exposed Duterte's online troll army, questionable procurement deals, and impunity in the drug

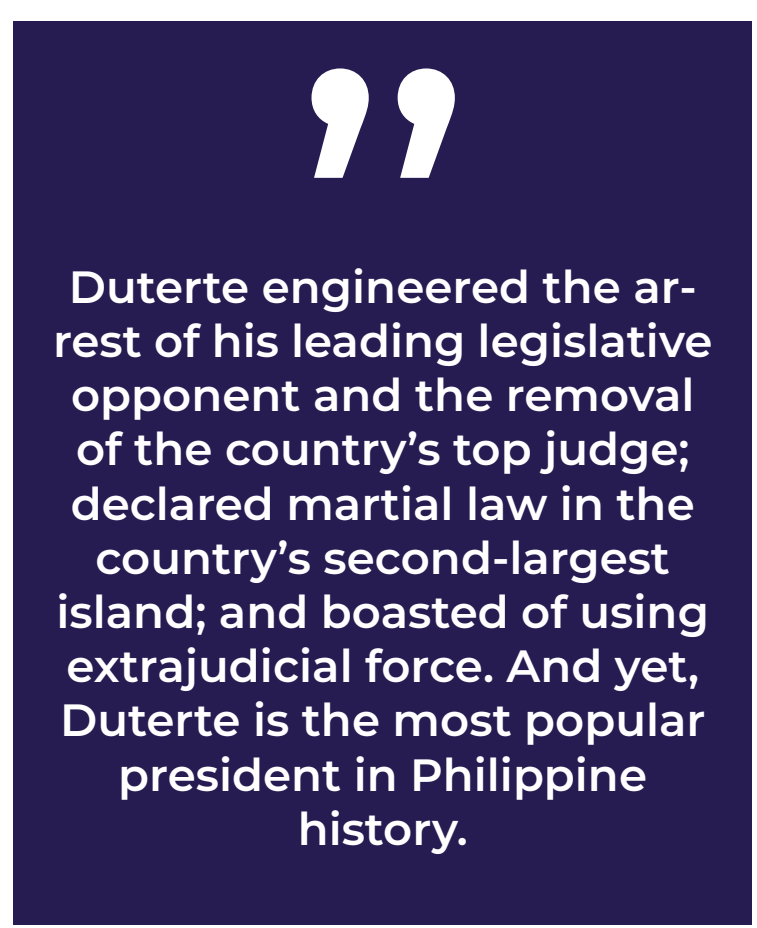


war - began running an extraordinary series called, "'Some People Need Killing' - Murder in Manila" by journalist Patricia Evangelista. The six-month investigation details how the police used and sometimes paid vigilantes, gang members, and others to ratchet up the body count in the grimmest district of Tondo, the worst slum in Manila. In the series, which is street-level reporting at its best, a young thug named Angel details how he was recruited into a vigilante gang by police and middlemen and was paid per killing. "Every time they said we had a job, they meant we were going to kill," Angel is quoted as saying (Guthrie, 2018).

\section{Dutertismo: Demise of Democracy}

Away from the carnage on the streets of Manila and other parts of the country, Duterte has generated controversy on the world stage. Like Trump, Duterte is given to surprising outbursts, such as when he called both US President Barack Obama and Pope Francis a "son of a whore" in Tagalog. He has shown little patience with the formal aspects of diplomacy, showing up late for summit meetings, dressed informally, and sometimes even skipping key events (Vatikiotis,2018). He engineered the arrest of his leading legislative opponent and the removal of the country's top judge; declared martial law in the country's second-largest island; and boasted of using extrajudicial force. And yet, Duterte is the most popular president in Philippine history (Capozzola, 2018). Why?

According to Capozzola, almost every explanation begins in the middle of an urban highway. From February 22-25, 1986, as many as a million Filipinos gathered on Manila's Epifanio de los Santos Highway (EDSA) to prevent President Marcos from attacking a group of military defectors who had broken with his regime to support Corazon Aquino in the aftermath of elections widely viewed as fraudulent. Filipino political culture was reborn in these four days, creating a democratic vocabulary and expectations for sweeping reforms even as entrenched elites contin- ued business as usual (Capozzola, 2018).

More than 30 years later, it is clear that "People Power" did not bring about the expected transformation. Politicians prattled on about the "unfinished" revolution but offered little explanation for why so many tasks were long left undone; meanwhile, doors opened for media-savvy populists. While ordinary people endured grinding poverty, a rising middle class demanded infrastructure, public safety, and an end to corruption. The poor wanted someone to speak for them, and the middle class wanted the government to do something. Both were disappointed. This was a ticking time bomb, and the election of Duterte was its explosion (Capozzola, 2018).

Like many observers, Heydarian sees Duterte as the culmination of three decades of political crisis. He argues strenuously for the existence of "Dutertismo," political ideology and approach to governance that draws from Duterte's "deep and diversified base" and targets his enemies at the expense of basic liberal principles (Capozzola, 2018). Thus, under the rule of Duterte, democracy in the Philippines has backslid towards authoritarianism.

Aminuddin (2020) argues that three key factors are driving the current recession of democracy in the Philippines. The first factor is the use of populism in political campaigns. This results in elected leaders being held hostage by their own political promises, which have the potential to inflict damage on democratic institutions, practices, and values(Aminuddin, 2020). Populism, as political theorist Simon Tormey (2018) puts it, is a pharmakon, "a powerful substance intended to make someone better, but which might end up killing him or her" (Curato, 2019). The second key factor is the political marginalization - used by presidents and their respective oligarchies - of their political rivals. This is accomplished through both repression and hegemonic power, weakening the opposition and public control of the ruling regime's performance. The third factor is the weakening of public institutions through policies created by politicians that support the regime (Aminuddin, 2020). 
As mentioned above, Duterte's government uses the legal system to attack political opponents, disparage or threaten leaders of key accountability institutions, and batter the mainstream media with lawsuits and criminal charges (Medina-Guce \& Galindes, 2018). However, voters in May 2019 delivered a resounding endorsement of his agenda by backing a slate of pro-Duterte candidates. Duterte maintained his hold on the House of Representatives, and, by taking control of the Senate, he removed what was the only effective check remaining on his administration (Ray, 2020). Beyond Duterte's overt displays of toxic masculinity is a discernible pattern of his aggressive attacks against the integrity of democratic institutions. His regime has demonstrated its willingness to breach the boundaries of state power while evading accountability (David, 2016 \& Thompson, 2017b).

The Philippines' presidential system allows presidents to utilize state-level repression with very limited constraints from other branches. This led many scholars to classify the Philippines as an example of Guillermo O'Donnell's $(1994,1996)$ delegative democracy - political systems that have not completely transitioned from authoritarianism to democracy and thus maintain autocratic features where the president employs coercive strategies against the country's people (Thompson 2017a; Pilapil 2016). According to O'Donnell, such polities are characterized by the elevation of the chief-executive as the true "embodiment of the nation, the custodian and definer of its national interest" and one that assumes a "paternalistic" role for his subjects. This arises because legislatures and the courts lose their ability to regulate the rule of law, and thus such institutions are likely to have no real political power except to rubber-stamp presidential directives(Tusalem, 2019).

In such a system, the president maintains his legitimacy through vertical accountability with the people, and, as such, his/her campaign promises must be translated into real, actionable programs to sustain his/her continued popularity. Thus, the president is above all political parties and organized interest groups, as his/her only sole purpose is to promote an agenda that continues to cater to the will and desires of the masses (Tusalem, 2019). Running on a platform based on this brand of populism, Duterte was able to gain support among an exhausted population made apathetic by political instability and economic mismanagement. More specifically, the public embraced Duterte's dichotomy between "virtuous citizens versus hardened criminals - the scum of society" (Curato 2017b).

To show who he supported in this dichotomy, in December 2019, Duterte threatened to beat up and jail the "oligarchs" who run Manila's water concessions, accusing them of bilking the government and overcharging consumers. "No matter how many bodyguards you have," he said at a public meeting, "I can ruin your face, son of a bitch." As their share prices went into a tailspin after the president's attacks, the heads of the country's two biggest business conglomerates agreed to renegotiate the water contracts and give up the hefty awards the government owed them. One company even ceded control of its water business to a businessman on friendlier terms with the president (Coronel, 2020).

Duterte's dystopian depiction of drugs as the root of all social ills has been a successful deflection strategy, distracting Filipinos from the country's limited developmental gains and shifting the blame for social problems onto criminals, who can be ruthlessly targeted in the name of national progress (Thompson, 2018). Duterte also campaigned on a promise of challenging the elitist democratic institutions in the country. These same institutions have been unable to bring needed reforms and have failed to unleash the country's economic and political potential (Heydarian 2017). He has made good on his word, moving to eliminate liberal barriers to his agenda.

He has also sought to sideline domestic critics by intimidating independent media, government institutions, and civil society groups, whom he accuses of "coddling" criminals (Thompson, 2018). His campaign was entirely based on restoring peace and order based on a populist sentiment that the country had become a "narco-state" (Quimpo 2017). Duterte believes that the Philippines will be unable 
to sustain its economic growth trajectory and remain politically stable unless the government eradicates drug use among its population. This platform was then translated into action as "Oplan-Tokhang" (Tusalem, 2019).

Perhaps the most disturbing aspect of Duterte's tenure so far is the manner in which he has dealt with the political opposition. Critics have been handled harshly and often threatened with violence. At the beginning of his presidency, he successfully had one of his leading critics in the Senate, Leila de Lima, who cut her teeth investigating the Davao Death Squads, imprisoned on improbable drug charges after he publicly "slutshamed" her (Thompson, 2018). However, Duterte's efforts to jail another opposition senator, Antonio Trillanes IV, have backfired. Trillanes, a retired army officer who helped plot a coup against the unpopular former president Macapagal Arroyo, has accused Duterte and several of his top officials of corruption and has suggested that his son and son-in-law are both involved in drug smuggling (Thompson, 2018).

Supreme Court Chief Justice Maria Lourdes Sereno was also removed - and almost without a whimper. She was also a critic of Duterte's "war" (Vatikiotis, 2018). Lawyers described the purge of Sereno as the "final nail in the coffin of judicial independence" (Minda News, 2018). The first female chief justice had a tense relationship with the macho president. Early in Duterte's term, Sereno reminded Duterte that only the judiciary had the right to discipline judges, after he had publicly accused a number of them of being part of the drug trade. Duterte threatened Sereno, claiming she should not create a crisis, "because I will order everybody in the executive department not to honor you" (Lorena, 2018). These threats became even harsher in 2018. Duterte put Sereno "on notice" that "I am your enemy and you have to be out of the Supreme Court." Duterte demanded that Congress fasttrack Sereno's impeachment, and Congress dutifully acted (Cruz, 2018).

Parallel to the impeachment proceedings, in Congress, a case was filed by Solicitor General Jose Calida to consid- er Sereno's appointment void from the beginning. Sereno was accused of failing to accurately declare her wealth in her Statement of Assets, Liabilities and Net Worth when she applied for the post of chief justice. This, according to the solicitor general, calls into question her integrity, thereby disqualifying her from holding public office. With a vote of eight against six, the Supreme Court made history by removing its own chief (Curato, 2019).

Duterte also tends to take repressive actions through parliament, where leftwing parties and politicians have become his main allies and support his populist policies, such as the Tax Reform Program, which provides benefits to the middle class. It was an exceptional case when Duterte supported the Anti-Political Dynasty Bill of 2018 but failed to get approval from Congress. His support was questionable - he comes from a political family, his children also hold public office, and his daughter is mentioned as a future successor to the top office. Similarly, many legislators supporting him also belong to political dynasties (Aminuddin, 2020).

Duterte has extended his crackdown on opponents to every corner of society. He has been particularly vicious against the Catholic Church, which has been critical of his war on drugs. Duterte has called the church "the most hypocritical institution in the entire Philippines," accused the clergy of abusing boys and coddling drug dealers, and threatened to behead a bishop who provided sanctuary to witnesses of police abuses in the drug war. In even more heavy-handed moves, Duterte has used his propaganda machine to shave off support for liberal opposition, and his state lawyers have hounded the most outspoken dissenters with aggressive prosecution. As a result of this campaign, Duterte has a near-monopoly on political power (Coronel, 2020). 


\section{7}

The pandemic did not halt but instead furthered Duterte's illiberal project is best instantiated in the shutdown of ABS-CBN - a media giant Duterte singled out in his previous speeches for its alleged bias against him. The last time the network went off the air was in 1972 during the Marcos dictatorship.

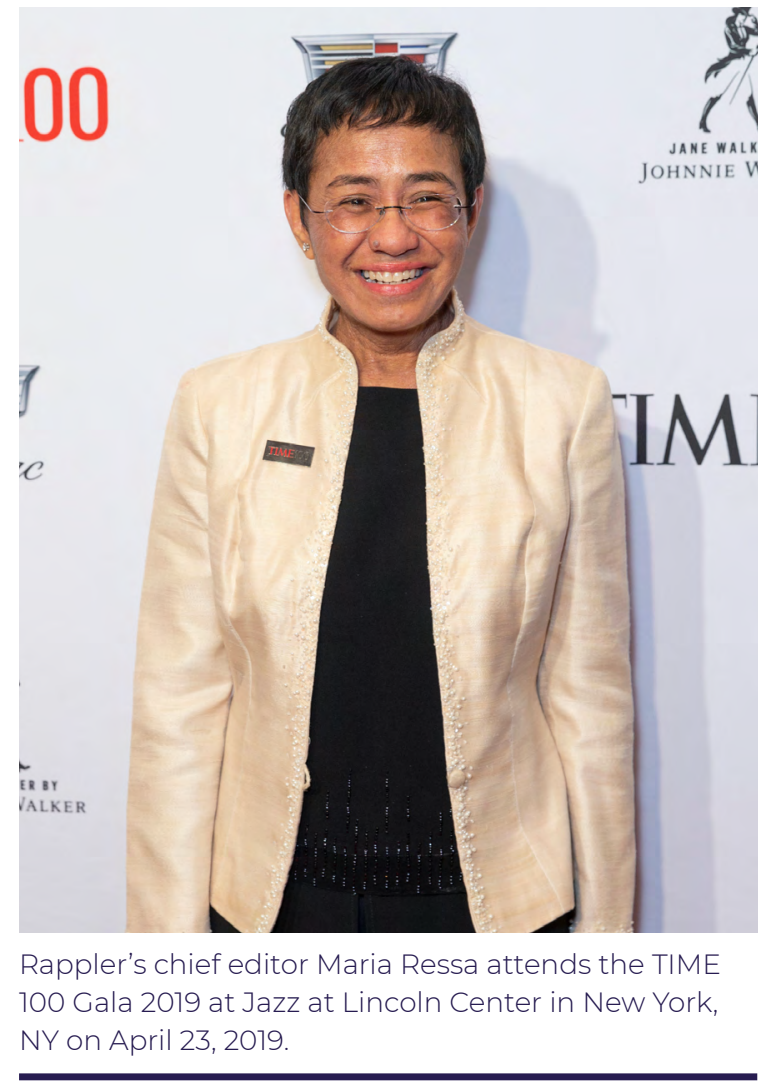

Having threatened, bullied, and jailed many of his opponents, Duterte has also cowed much of the media into submission and curtailed press freedoms. Maria Ressa, the cofounder of a news website Rappler - which documented the worst excesses of Duterte's anti-drug campaign - was arrested numerous times on questionable charges (Ray, 2020).

Since he took office, Duterte has been persistent in accusing Rappler of violating the constitutional requirement for mass-media organizations to be $100 \%$ Filipino owned. Rappler is American-owned, Duterte claims. He also claims it is backed by the CIA and out to destabilize his administration. Rappler denies these claims
(Curato, 2019).

"It is easier to navigate a conflict zone, a war zone than it is to navigate the social media and the legal weaponization of laws in our country. But we hold the line," Rappler's chief editor Ressa stated. The two areas of Rappler's coverage that seem to have most unnerved Duterte revolve around significant investigations of police impunity in the drug-war killings and the continued use of Facebook to spread disinformation and distortion for political ends (Guthrie, 2018).

On January 15, 2018, the Securities and Exchange Commission revoked Rappler's license to operate, claiming violations of the Foreign Equity Restriction of the Philippine Constitution. A month later, Rappler's Malacañang correspondent Pia Ranada was banned indefinitely from covering the president. The eight-year-old media start-up also found itself facing a cyber-libel complaint and five charges of tax evasion, together with unrelenting online death threats to its journalists(Curato, 2019). Duterte is belligerent and has warned the media about the limits of press freedom. "It's a privilege in a democratic state," he said. "You have overused and abused that privilege" (Salaverria, 2018).

The weakening of the political opposition has been aided by the regime's aggressive intimidation of the press. Duterte's other targets include the Philippine Daily Inquirer, which had been the most respected newsgroup in the country before it caved to political pressure on its businesses and sold out to an ally of Duterte. Other outlets still challenge Duterte, 
including to some extent the country's largest TV news network, ABS/CBN (Guthrie, 2018).

Duterte is aware of using social media to control his agenda. He applies so-called Key Internet Protocols, or KICS, to censor online media, limits information, and launch technical attacks on government critics. The attacks on freedom of expression on social media or in conventional media are of concern because they are often followed by physical attacks or torture (Aminuddin, 2020).

In reality, the Philippines has one of the most vibrant media landscapes in the region, but it is also one of the most dangerous places to practice journalism. Long before Duterte threatened the media, the Philippines had some of the highest incidences of journalists being killed in the world. Journalism in the Philippines is a dangerous enterprise, made even more toxic by a president who sees journalists as the enemy.

Duterte has shamed the Philippine Daily Inquirer and ABS-CBN News as "rude" in his speeches. "See how they slant," he complained. "I'm not scaring them, but someday, karma will come." Observers read this as a clear threat to two of the country's biggest media organizations. The ABS-CBN franchise is up for renewal in 2020. Duterte has said that if it were up to him, he would not renew it (Rappler, 2017). After 12 hearings, the House Committee on Legislative Franchises rejected the franchise application of the ABS-CBN Corporation (de la Cruz, 2020).

The pandemic did not halt but instead furthered Duterte's illiberal project is best instantiated in the shutdown of ABSCBN - a media giant Duterte singled out in his previous speeches for its alleged bias against him. The last time the network went off the air was in 1972 during the Marcos dictatorship. The network was forced to go off the air at the height of the pandemic because its franchise was not renewed. There are many implications of the network's shutdown. Aside from curtailing press freedom, ABS-CBN's absence means many Filipinos living in far-flung and vulnerable areas have no access to news and information not only about the pandemic but also about forthcoming disasters including the destructive Typhoon VongFong (Curato, 2020).

\section{Duterte Makes New Friends From Old Enemies or Vice Versa}

Ever since independence in 1946, every Filipino president has walked a fine line between insisting on an "independent foreign policy" and burnishing close connections to Washington (Capozzola, 2018). Duterte has also long wanted to end the Philippines' dependence on the US security umbrella and foreign aid; past presidents were forced to come to heel when American officials threatened to withhold assistance in an effort to rein in corruption and human rights abuses. Therefore, Duterte has called for a "separation" from the US and advocated closer ties with China, believing that the Philippines' longterm security and economic interests are best served by Beijing's embrace (Coronel, 2020).

In the months after his presidential victory, Duterte stirred the global political arena by announcing his radical departure from long-standing Philippine diplomatic relations with the US and his

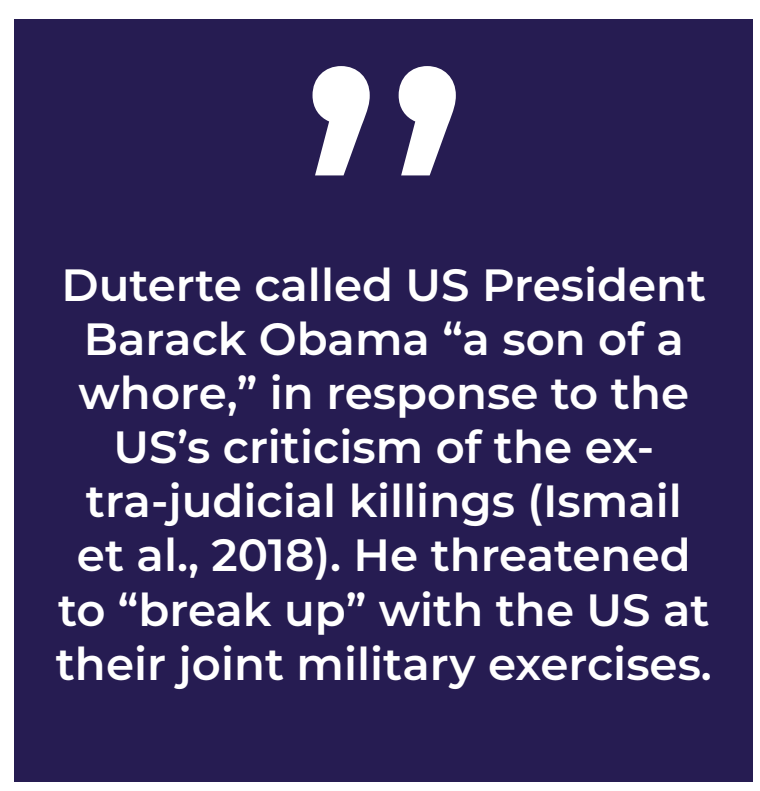


subsequent shift to an alliance with China (Montiel et al, 2019). The Chinese Ambassador was among the first foreign envoys who met Duterte after his victory. During his campaign, Duterte said that he would continue a stance toward multilateral negotiations on the disputes over maritime claims in the South China Sea. He has also encouraged China to invest more in the Philippines and engage in further economic cooperation (Kundu, 2016).

On September 5, 2016, Duterte called US President Barack Obama "a son of a whore," in response to the US's criticism of the extra-judicial killings (Ismail et al., 2018). He threatened to "break up" with the US at their joint military exercises(Ranada, 2016a). During his state visit to China in October 2016, Duterte declared to Chinese officials, "I announce my separation from the United States, both militarily but also economically ... So, please, you have another problem of economics in my country. I am separated from them so I will be dependent on you for a long time" (Ranada, 2016b). Following Duterte's shift in allegiance, China generously provided financial assistance to the Philippines, offering aid in the construction of major local infrastructure projects, including major bridges, expressways, and even rehabilitation of a war-torn city (de Vera, 2017).

China has continued to lend significant funds to an ambitious public works program, and Chinese businesses and tourists bring much-needed investments and foreign exchange to the Philippines. Unlike the US, China offers these benefits without pressing Duterte to give ground on democracy and human rights (Coronel, 2020). However, high-profile visits by Duterte to Beijing aside, the basics of the US-Philippine military relations have not changed: the Mutual Security Act commits the US to military protection, while the Enhanced Defense Cooperation Agreement allows joint maneuvers, training, and ship visits. Heydarian argues this is not an erratic or inconsistent foreign policy but one that "follows a strategic logic which is sensible for smaller powers precariously caught between competing superpowers" (Capozzola,2018).
When Western governments expressed concern over the rampant vigilantism, Duterte said that the West could offer the Philippines only "double talk." When the US went beyond talking and suspended the sale of 26,000 assault rifles to the Philippines, Duterte met with Russian President Vladimir Putin in May 2017 to discuss the prospect of an arms deal (Ray, 2020). Duterte successfully showed that the country's sovereignty cannot be compromised by business interests. Similarly, it may not be difficult for Duterte to assert his country's sovereignty despite its economic dependence on China. In response, the international community has threatened economic sanctions while the US government has cut off some overseas development assistance to the Philippines, with Duterte lambasting officials of the $\mathrm{EU}$ and the US government as disrespectful of his country's right to self-determination-often giving speeches laden with profanities and obscenities against world leaders and threatening to withdraw from international human rights organizations, treaties, and obligations(Tusalem, 2019).

Foreign direct investment (FDI) continues to pour into the country, although this may have less to do with the approval of the regime, and more to do with the opportunities offered by the government's ambitious infrastructure spending program and the momentum resulting from steady economic growth throughout the 2010s. Data from the Central Bank of the Philippines show that total net foreign investments increased in all years that Duterte has been in power so far, compared to their levels in 2015. While there have been fluctuations in FDI from Japan, the US, and the European Union, Chinese FDI steadily increased from 2015 to 2018, reaching unprecedented levels in 2018 and 2019 (Ramos, 2020). Foreign investment from China increased 10 percent in the early period of Duterte's presidential term (Cigaral, 2019). They flowed mostly into promised infrastructure projects. With the Duterte administration's multi-trillion-peso flagship "Build, Build, Build" program, the National Economic and Development Authority envisions that the Philippines will be a high-middle-income country by the end of Duterte's term (Curato, 2019). Duterte is hedging his bets on Chinese investments to finance 
this economic vision. While the Aquino administration took a proactive approach against China in pursuing territorial claims, Duterte takes a pragmatic route, preferring bilateral negotiations and the joint development of resources(Aminuddin, 2020).

Since 2016, shortly after Duterte took office, more than 3 million Chinese nationals have visited the country. This resulted in rising public anxiety about the number of illegal workers (Aminuddin, 2020). Nevertheless, superpower talk rarely stirs widespread public emotion, because the majority of the voting population concern themselves with local issues. However, when a populist leader wins and governance begins, she/he may decide which global superpower best suits the country's needs for effective governance. In the case of the Philippines, this also includes optimal logistical and ideological support for the authoritarian rule (Montiel et al, 2019). More specifically, leaders in countries with weak economies need foreign aid for advanced military equipment, training of armed forces personnel, and potentially even foreign militarized consultants during escalations of intrastate armed confrontations (Grant, 2010; Hawkins, 2008).

Duterte believes China can fulfill these needs. Before he left for China in April 2018, he publicly declared his "love" for Xi Jinping. And during Xi's state visit, twenty-nine deals were signed. The most controversial of these deals is a memorandum of understanding covering the joint exploration of oil resources in the South China Sea. The skepticism regarding China resonates with the public. Xi's visit was met with protests all over Manila demanding that China get out of Philippine waters (Curato, 2019). 


\section{CONCLUSION}

Duterte is, of course, a populist, but he is also a pragmatist. The utilitarian logic behind Duterte's decision-making is best described by the words of Kovács and Lynch, who wrote that "Drugs are a problem in the Philippines. What is the most direct way of dealing with it? Kill drug pushers and users. Is it feasible? Yes. Let us do it. China is encroaching on Philippine maritime territory. Is it possible to repel China? No. Let us deal with China, then. The insurgencies are a fundamental challenge to the state and a major loss of treasure and life. Can they be defeated? No. Let us negotiate peace with them. All these are part of what adds up to an effective nation-building project, perhaps not planned, but playing out so." And from the outside, it appears Duterte does implement the policy most convenient for him at a particular moment(Kovács \& Lynch, 2016).

Curato (2020) wrote that Duterte's initially ambiguous ideological position became clear four years into his term. Having rid his cabinet of progressive politicians and populating them with retired military generals, Duterte's illiberal project is getting consolidated as time goes by. The Covid-19 pandemic gave Duterte the justification to further tighten the control of security forces, especially in the capital.

In the Philippines, most presidents become lame ducks halfway into their six-year terms. But four years into his presidency, Duterte remains at the top of his game, impervious to blistering criticism of his autocratic tendencies and his bloody war on drugs. A December 2019 poll shows his popularity at 87 percent, surpassing that of every Philippine president since competitive elections were reintroduced in the 1980s. His opponents hope that "Dutertismo" will fade away in 2022 when his term ends. But they should not assume that Duterte will quietly leave office like his predecessors(Coronel, 2020).

According to Coronel (2020) Duterte's demonstration of power may be thuggish, but it is also methodical. From his 21 years as mayor of Davao, he learned that citizens respect and follow a strong leader. He is an avid reader of Nietzsche and Machiavelli and likes to quote from "The Prince." He's a student of power, which means that despite his seemingly irrational fits of public rage, Duterte plays the long game.

Buoyed by public support, Duterte is making every effort to consolidate his base, cement his legacy, and handpick a successor so he can continue to exert influence and exercise power beyond his term. If he succeeds, then Duterte's illiberalism, anti-Westernism, and anti-elitism may endure for years to come. Duterte has fanned rumors he will field either his daughter Sara or his former aide Senator Go in the 2022 presidential race. He has let slip that his daughter may succeed him. Some observers speculate that Duterte will run as vice president on the same ticket as his successor, thus setting himself 
up to continue exercising power (Coronel, 2020). Dutertismo seems set to remain, either with Duterte or without him, for the foreseeable future - even after his mandate as a populist, jingoist, macho president ends. 


\section{REFERENCES}

- (2016). "Rodrigo Duterte: Philippines Presidential Candidate Hits Back as Rape Remark Sparks Fury." ABC News.com, April 18, 2016. https://www.abc.net.au/news/2016-04-18/rodrigo-duterte-hits-back-back-as-rape-remark-sparks-fury/7333532

- (2016). "Duterte Catcall GMA News Reporter Mariz Umali." Youtube. June 2, 2016. https://www.youtube.com/watch?v=2MLGdL6w2ag (accessed on August 31, 2020).

- (2016). "Philippines: Duterte confirms he personally killed three men." BBC News. December 16, 2016. http://www.bbc.com/news/world-asia-38337746 (accessed on August 31, 2020).

- (2016). "Pulse Asia Research's January 2016 Nationwide Survey on Urgent National Concerns to be Addressed by Presidential Candidates and Most Important Consideration in Choosing a Presidential Candidate." Pulse Asia ResearchInc., February 19, 2016.

- (2016). "Hot-button issues in the Philippine presidential election." Philippine Daily Inquirer. May 9, 2016.

— (2017). “Duterte's Target: The Philippine Daily Inquirer." Rappler. August 16, 2017.

https://www.rappler.com/newsbreak/in-depth/178715-duterte-target-philippine-daily-inquirer (accessed on Sept.3. 2020).

- (2017). The Human Rights Consequences of the War on Drugs in the Philippines. Tom Lantos Human Rights Commission. July 20. https://humanrightscommission.house.gov/ sites/humanrightscommission.house.gov/files/documents/Bios\%20sheet\%20-\%20Phillipines.pdf (accessed on September 7, 2019).

- (2018). "FLAG STATEMENT: "Final nail in the coffin of judicial independence." Minda News. May 12, 2018. http://www.mindanews.com/statements/2018/05/flag-statement-finalnail-in-the-coffin-of-judicial-independence/ (accessed 12 December 2018).

- (2019). "Filipinos give thumbs up to Duterte's excellent drugs war: Poll." Reuters. Sept. 23, 2019. www.reuters.com/article/us-philippines-drugs/filipinos-give-thumbs-up-to-dutertesexcellent-drugs-war-poll-idUSKBN1W803M (accessed on August 31, 2020).

- (2020). Rodrigo Duterte Biography. The Famous People. https://www.thefamouspeople. com/profiles/rodrigo-duterte-7713.php\#childhood-\&-early-years (accessed on August 31, 2020).

Abts, K., \& Rummens, S. (2007). "Populism versus democracy." Political Studies. 55, 405-424.

Aminuddin, M. Faishal. (2020). "Populist Promises, Democratic Fissures: Indonesia and the Philippines." Global Asia,Vol. 15, No. 1. https://globalasia.org/V15nol/cover/populist-promises-democratic-fissures-indonesia-and-the-philippines_m-faishal-aminuddin (accessed on July 2, 2020).

Arguelles, Cleve. (2016). "How the Philippines' incomplete 'people power' revolution paved the way for Rodrigo Duterte." The Conversation. December 20, 2016. http://theconversation. $\mathrm{com} / \mathrm{how}$-the-philippines-incomplete-people-power-revolution-paved-the-way-for-rodrigo-duterte-65972 (accessed 31, 2020).

Arguelles, Cleve. (2017). Grounding populism: Perspectives from the populist publics (MA thesis). Budapest, Hungary: Department of Political Science, Central European University. 
Arguelles, Cleve. (2018). "'We hate the killings, We love the war on drugs': Rodrigo Duterte's enduring political strength in Manila slum." Institute for Leadership, Empowerment, and Democracy. September 3, 2018. http://ilead.ph/2018/09/03/we-hate-the-killings-we-lovethe-war-on-drugs-rodrigo-dutertes-enduring-political-strength-in-manila-slum/ (accessed on August 31, 2020).

Arguelles, Cleve V. (2019). "'We Are Rodrigo Duterte': Dimensions of the Philippine Populist Publics' Vote." Asian Politics \& Policy. Vol. 11, No. 3 (2019): 417-37.

Bello, Walden. (2017). "Rodrigo Duterte: A fascist original." Foreign Policy in Focus. January 6, 2017. https://fpif.org/rodrigo-duterte-fascist-original/(accessed on August 31, 2020).

Capozzola, Christopher. (2018). "President Duterte: How and Why?" Global Asia (East Asia Foundation). Vol. 13, No. 2 (2018): 118-20. https://globalasia.org/v13no2/book/president-duterte-how-and-why_christopher-capozzola (accessed on July 2, 2020).

Christie, Daniel. (2009). "Reducing direct and structural violence: The human needs theory." Peace and Conflict: Journal of Peace Psychology, 3(4), 315-332.

Cigaral, Ian Nicolas. (2019). "Duterte to maintain warm Philippine-China relations to boost economy." Philstar. Sept. 20, 2019. www.philstar.com/business/2019/09/20/1953501/duterte-maintain-warm-philippine-china-relations-boost-economy (accessed on Sept. 3, 2020).

Clement, Hugh. (2016). Duterte's supporters hold banners that say: "Ang hindi bumoto kay Duterte, patay!" Philippine News. April 27, 2016. https://philnews.ph/2016/04/27/duterte-supporters-issue/ (accessed on August 31, 2020).

Coronel, Sheila. (2019). "The Vigilante President: How Duterte's Brutal Populism Conquered the Philippines." Foreign Affairs. September/October. www.foreignaffairs.com/articles/philippines/2019-08-12/vigilante-president (accessed on September 8, 2020).

Coronel, Sheila S. (2020). "Rodrigo Duterte Will Not Go Gently." Foreign Affairs, March 11, 2020.

Cruz, Maricel. (2018). "Three SC Justices Gang up on Sereno at House Hearing." Manila Standard, January 17, 2018. http://manilastandard.net/news/top-stories/256485/three-sc-justices-gang-up-on-sereno-at-house-hearing.html (accessed on Sept.3, 2020).

Cumming-Bruce, Nick. (2019). "Rights Experts Urge UN Inquiry into 'Staggering' Killings in Philippines." New York Times. June 7. https://www.nytimes.com/2019/06/07/world/asia/philippines-killings-un.html (accessed on Sept.7, 2020).

Curato, Nicole. (2017a). A Duterte Reader: Critical essays on Rodrigo Duterte's early presidency. Ithaca, NY: Cornell University Press.

Curato, Nicole. (2017b). "Flirting with Authoritarian Fantasies? Rodrigo Duterte and the New Terms of Philippine Populism." Journal of Contemporary Asia, 47, no. 1 (2017): 142-53.

Curato, Nicole. (2017c). "Politics of anxiety, politics of hope: Penal populism and Duterte's rise to power." Journal of Current Southeast Asian Affairs. 35(3), 91-109.

Curato, Nicole. (2019). "Toxic Democracy? The Philippines in 2018." Southeast Asian Affairs. 261-74.

Curato, Nicole. (2020). "Philippines." Populism \& the Pandemic Report, ed. Giorgos Katsambekis Yannis Stavrakakis. POPULISMUS Interventions No. 7, June, 2020.

David, Randy. (2016). "Dutertismo." Philippine Daily Inquirer. May 1, 2016. 
https://opinion.inquirer.net/94530/dutertismo (accessed on Sept.3, 2020).

de la Cruz, Jovee Marie. (2020). "House panel votes 70-11 against ABS-CBN franchise application." Business Mirror.July 10, 2020. https://businessmirror.com.ph/2020/07/10/housepanel-votes-70-11-to-reject-abs-cbn-franchise-renewal// (accessed on September 7, 2020).

de Vera, Ben O. (2017). "China commits financing for 12 PH infra projects." Inquirer.net. October 2. http://business.inquirer.net/237866/china-finance-fund-infrastructure-infra-project-marawi-city-dof (accessed on September 8, 2020).

Fink-Hafner, D. (2016). "A typology of populisms and changing forms of society: The case of Slovenia." Europe-Asia Studies. 68(8), 1315-1339.

Gavilan, Jodesz. (2016). "Data in the drug war: Why accurate numbers matter Rappler." Rappler. November 4, 2016. https://rappler.com/newsbreak/iq/data-drug-war-accuracy-statistics-matter (accessed on Sept.7, 2020).

Grant, C. (2010). "Europe, China, India and the multipolar world order." In C. Chari (Ed.). Superpower rivalry and conflict: The long shadow of the cold war on the twenty-first century (pp. 110-123). New York: Routledge.

Guthrie, Edward. (2018). "Challenging Duterte: Maria Ressa and the Philippine Media." Global Asia (East Asia Foundation). Vol. 13, No. 4 (2018): 94-98. https://globalasia.org/v13no4/ feature/challenging-duterte-maria-ressa-and-the-philippine-media_edward-guthrie (accessed on July 2, 2020).

Hadro, Matt. (2017). "Duterte's Bloody War on Drugs Slammed as 'Social Cleansing." Catholic News Agency. July 23, 2017. www.catholicnewsagency.com/news/dutertes-bloody-waron-drugs-slammed-as-social-cleansing-90957 (accessed on Sept. 3, 2020).

Hawkins, V. (2008). Stealth conflicts: How the world's worst violence is ignored. England: Ashford.

Heydarian, Richard J. (2017). The Rise of Duterte: A populist revolt against elite democracy. London: Palgrave.

Holmes, Ronald. (2016). "The dark side of electoralism: Opinion polls and voting in the 2016 Philippine presidential election." Journal of Contemporary Southeast Asia. 35(3), 15-38.

Ismail, Natasha Binte Mohamed, Pagulayan, Marie Angeline, Francia, Carlo Miguel Alfonso, and Pang, Augustine. "Communicating in the Post-truth Era: Analyses of Crisis Response Strategies of Presidents Donald Trump and Rodrigo Duterte." Journal of Public Affairs 19, no. 1 (2018): E1883-N/a.

Kenny, P. (2017). Populism and Patronage: why populists win elections in India, Asia, and Beyond, London, Oxford University Press.

Kenny, P. (2018). "A New Penal Populism? Rodrigo Duterte and the War on Drugs in the Philippines." Paper presented at the National Congress Meeting of the International Political Science Association. Brisbane, Australia.

Kovács, Balázs Áron \& Lynch, Tony. (2016). "Is Duterte 'Nation-Building' in the Philippines?" The Diplomat. October 11. http://thediplomat.com/2016/10/is-duterte-nation-building-in-the-philippines (accessed on September 8, 2020).

Kundu, Sampa. (2016). “The 'Unpredictable' Duterte: It's Too Early to Imagine the 'Filipino Way' in the Making." Global Asia. June 2, 2016. https://globalasia.org/bbs/board.php?bo_ table=forum\&wr_id=9226 (accessed on July 2, 2020). 
Lorena, Nicole. (2018). "Timeline: The Many Times Duterte and Sereno Clashed." Rappler. May 20, 2018. https://amp.rappler.com/newsbreak/iq/202763-timeline-maria-lourdes-sereno-rodrigo-duterte-clashes (accessed on Sept.3, 2020).

Mangahas, Mahar. (2016). "Revelations of the TV5-SWS exit poll." Philippine Daily Inquirer. May 14, 2016. https://www.fef.org.ph/mahar-mangahas/revelations-of-the-tv5-sws-exit-poll/ (accessed on Sept.7, 2020).

McCargo, Duncan. (2016). "Duterte's Mediated Populism." Contemporary Southeast Asia. Vol. 38, No. 2: 185-90.

McCoy, Alfred. (2017b). "Philippine populism: Local violence and global context in the rise of a Filipino strongman." Surveillance \& Society. 15(3/4), 514-522.

Medina-Guce, C. and Galindes, A.M. (2018). Democratic Backsliding \& Shrinking Civic Spaces: Problematizing the Strengthening of Philippine Democratic Institutions. Working paper, Institute for Leadership, Empowerment and Democracy, Quezon City, 2018.

Moffitt, B., \& Tormey, S. (2014). "Rethinking populism: Politics, mediatisation and political style." Political Studies. 62, 381-397.

Montiel, Cristina Jayme; Boller, Arvin Jay; Uyheng, Joshua, and Espina, Ervina A. (2019). "Narrative Congruence between Populist President Duterte and the Filipino Public: Shifting Global Alliances from the United States to China." Journal of Community \& Applied Social Psychology. 29, no. 6: 520-34.

Mudde, Cas. (2010). "The populist radical right: A pathological normalcy." West European Politics. 33(6), 1167-1186.

Kenny P. (2017). Populism and Patronage: why populists win elections in India, Asia, and Beyond. London, Oxford University Press.

Kenny, P. (2018). A New Penal Populism? Rodrigo Duterte and the War on Drugs in the Philippines. Paper presented at the National Congress Meeting of the International Political Science Association. Brisbane, Australia.

Kundu, Sampa. (2016). "The 'Unpredictable' Duterte: It's Too Early to Imagine the 'Filipino Way' in the Making." Global Asia. June 2, 2016. https://globalasia.org/bbs/board.php?bo_ table=forum\&wr_id=9226 (accessed on July 2, 2020).

Kusaka, Wataru. (2017). Moral politics in the Philippines: Inequality, democracy, and the urban poor. Singapore: National University of Singapore Press.

Lamchek, J.. (2017). "A mandate for mass Killings? Public support for Duterte's war on drugs." In Curato, N. (Ed.), A Duterte Reader: Critical Essays on Rodrigo Duterte's Early Presidency. Ithaca: Cornell University Press, pp.199-218.

Lema, Karen, \& Mogato, Manuel. (2016). “Philippines' Duterte likens himself to Hitler, wants to kill millions of drug users." Reuters. September 30, 2016. https://www.reuters.com/article/ us-philippines-duterte-hitler-idUSKCN1200B9 (accssed on August 31, 2020).

O'Donell, GA. (1994). "Delegative democracy." Journal of Democracy. 5, 1, 55, 69.

O'Donnell, GA. (1996). Illusions about consolidation, Journal of Democracy, 7, 2, 34, 51.

Panarina, D.S. (2017). "Rodrigo Duterte - Who Is He?" Vestnik Rossiǐskogo Universiteta Druzhby Narodov. Serii Mezhdunarodnye Otnosheni. Vol. 17, no. 3: 588-97. 
Pepinsky, Thomas. (2017). "Southeast Asia: Voting against disorder." Journal of Democracy. 28(2), 120-131.

Pilapil, Gene Lacza. (2016). "Duterte and delegative democracy." Philippine Inquirer. July 11, 2016. http://opinion.inquirer.net/95589/duterte-delegative-democracy (accessed on Sept. 3. 2020).

Quimpo, Nathan. (2017). "Duterte's war on drugs." In Curato, N. (Ed.), A Duterte Reader: Critical Essays on Rodrigo Duterte's Early Presidency. Cornell University Press. pp.145-166.

Ramos, Charmaine G. (2020). "Change without Transformation: Social Policy Reforms in the Philippines under Duterte." Development and Change. 51, no. 2: 485-505.

Ranada, Pia. (2015). "Rodrigo Duterte: Yes, I'm a Womanizer." Rappler.com, November 30, 2015, http://www.rappler.com/nation/politics/elections/2016/114416-rodrigo-duterte-womanizer (accessed on August 31, 2020).

Ranada, Pia. (2016a). "Duterte: Next PH-US military exercises will be last in my term." Rappler. September 28. http://www.rappler.com/nation/147643-duterte-last-ph-us-military-exercises (accessed on September 8, 2020).

Ranada, Pia. (2016b). "Duterte announces military, economic split from US." Rappler. October 20. http://www.rappler.com/nation/149806-duterte-announce-military-economic-splitfrom-us (accessed on September 8, 2020).

Ray, Michael. (2020). "Rodrigo Duterte. President of the Philippines." Encyclopedia Britannica. March 24, 2020, https://www.britannica.com/topic/Rodrigo-Duterte (accessed on August 31, 2020).

Rodrik, Daniel. (2018). Is populism necessarily bad economics? AEA Papers and Proceedings, 108, 196-199.

Santos, Reynaldo. (2016). "Duterte SALNS Don't Match Alleged Bank Accounts." Rappler, April 29, 2016. https://rappler.com/newsbreak/in-depth/rodrigo-duterte-bank-accounts-saln (accessed on August 31, 2020).

Schaffer, Frederic Charles. (2007). Elections for sale: The causes and consequences of vote buying. Quezon City: Ateneo De Manila University Press.

Simangan, Dahlia. (2018). "Is the Philippine "war on drugs" an act of genocide?" Journal of Genocide Research, 20(1), 68-89.

Salaverria, Leila B. (2018). "Duterte, Rappler Clash over Fake News, Press Freedom." Philippine Daily Inquirer, January18, 2018. https://newsinfo.inquirer.net/961414/duterte-rapplerclash-over-fake-news-press-freedom (accessed on Sept. 3, 2020).

Taggart, Paul. (2004). "Populism and representative politics in contemporary Europe." Journal of Political Ideologies. 9(3), 269-288.

Teehankee, Julio. (2016). "Duterte's resurgent nationalism in the Philippines: A discursive institutionalist analysis." Journal of Current Southeast Asian Affairs. 35(3), 69-89.

Teehankee, Julio \& Thompson, Mark. (2016a). "The vote in the Philippines: Electing a strongman." Journal of Democracy. 27(4), 125-134.

Teehankee, Julio \& Thompson, Mark. (2016b). "Electing a strongman." Journal of Democracy. 27(4), 125-134. 
Thompson, Mark R. (2010). "Reformism vs. populism in the Philippines." Journal of Democracy, 21(4), 154- 168.

Thompson, M. R. (2017a). "The Philippine presidency in Southeast Asian perspective: imperiled and imperious presidents but not perilous presidentialism." Contemporary Politics. $1-21$.

Thompson, Mark. (2017b) "Bloodied Democracy: Duterte and the Death of Liberal Reformism in the Philippines." Journal of Current Southeast Asian Affairs. 35, no. 3 (2017): 39-68.

Thompson, Mark R. (2018). "Why Duterte Remains So Popular." Foreign Affairs, October 9 , 2018.

Timberman, David G. (2019). Philippines politics under Duterte: A midterm assessment. Carnegie Endowment, Jan. 10, 2019. www.carnegieendowment.org/2019/01/10/philippine-politics-under-duterte-midterm-assessment-pub-78091 (accessed on August 31, 2020).

Tomacruz, Sofia. (2018). “Duterte Government Tally: 'Drug War' Deaths Breach 5,000-mark before 2019." Rappler,December 31. www.rappler.com/nation/220013-duterte-government-tally-killed-war-on-drugs-november-2018 (accessed on Sept. 1, 2020).

Tormey, Simon. (2018). “Populism: Democracy's Pharmakon." Political Studies. 39, no. 3: 261.

Tusalem, Rollin F. (2019). "Examining the Determinants of Extra-Judicial Killings in the Philippines at the Subnational Level: The Role of Penal Populism and Vertical Accountability." Human Rights Review (Piscataway, N.J.). 20, no. 1: 67-101.

Vatikiotis, Michael. (2018). "Rodrigo Duterte: The 'Moderately Successful' Populist." Global Asia (East Asia Foundation). Vol. 13, no. 3: 40-45. https://globalasia.org/v13no3/cover/rodrigo-duterte-the-moderately-successful-populist_michael-vatikiotis (accessed on July 2, 2020).

Whaley, Floyd. (2016). "Rodrigo Duterte's Talk of Killing Criminals Raises Fears in Philippines." New York Times. May17, 2016. https://www.nytimes.com/2016/05/18/world/asia/rodrigo-duterte-philippines.html (accessed on August 31, 2020).

Zamora, Fe. (2016). "Law student Duterte shot frat brod on campus in '72." Enquirer.Net. April 22, 2016. http://newsinfo.inquirer.net/780836/law-student-duterte-shot-frat-brod-oncampus-in-72 (accessed on August 31, 2020). 


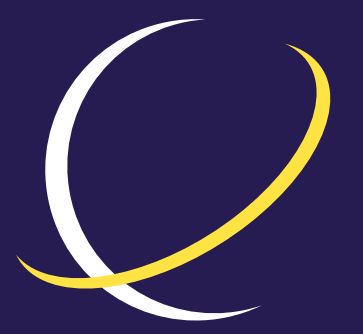

\section{ECPS \\ EUROPEAN CENTER for POPULISM STUDIES}

\section{ABOUT ECPS}

The European Center for Populism Studies (ECPS) is an independent, nonpartisan, nonprofit organization, based in Brussels, for research on and analysis of challenges posed by the resurgence of political populism. ECPS facilitates collaboration among networks of academic experts, practitioners, policymakers, media, and other stakeholders. ECPS offers a platform for the exchange of policy solutions on issues relating to rising populism and provides insights for policy-making and critical analysis to raise broader awareness and engagement through:

\section{Publications}

\section{Academic publications}

Policy reports

White papers

Commentaries

Podcasts and interviews with experts

Events, seminars, workshops, and conferences

\section{Research Programs}

Authoritarianism

Digital Populism

Economics

Environment \& Climate

Extremism \& Radicalisation

\section{Gender}

Human Rights

Foreign Policy

Leadership \& Persona

Migration

\section{ECPS Youth Program}

ECPS Academy 